\title{
Notes from the Northwest Louisiana Regional Archaeology Program
}

Jeff Girard

Northwestern State University of Louisiana

Follow this and additional works at: https://scholarworks.sfasu.edu/ita

Part of the American Material Culture Commons, Archaeological Anthropology Commons, Environmental Studies Commons, Other American Studies Commons, Other Arts and Humanities Commons, Other History of Art, Architecture, and Archaeology Commons, and the United States History Commons

Tell us how this article helped you.

This Article is brought to you for free and open access by the Center for Regional Heritage Research at SFA ScholarWorks. It has been accepted for inclusion in Index of Texas Archaeology: Open Access Gray Literature from the Lone Star State by an authorized editor of SFA ScholarWorks. For more information, please contact cdsscholarworks@sfasu.edu. 


\section{Notes from the Northwest Louisiana Regional Archaeology Program}

Creative Commons License

(c) (i) (8)

This work is licensed under a Creative Commons Attribution-NonCommercial 4.0 International License 


\title{
NOTES FROM THE NORTHWISTT LOUISLANA
}

\author{
REGIONAL ARCHABOLOGY PROGRAM
}

\author{
Jeffrey s. Girard
}

During the spring of 1990 a project was started by the Northwest Louisiana Regional Archaeology Program to re-locate and update information on sites in northwestern Louisiana initially investigated by Dr. Clarence Webb of Shreveport. A summary of information from several sites lkely to be of interest to Caddo archaeologists is presented here.

The Regional Archaeology Program is jointly sponsored by Northwestern State University and the Louisiana Division of Archaeology. The primary purpose of the program is to record and update information about archaeological sites in the region located on private and state lands. The program also will compile and manage a regional data base and communicate the need for conservation and protection of archaeological resources to landowners and the general public.

Dr. Webb recently donated his artifact collections to the Louisiana Division of Archaeology to be housed at the Williamson Museum at NSU. In conjunction with cataloging and inventorying the collection attempts are being made to re-visit the sites to check map plottings, establish site boundaries, and to update information about current conditions of the sites. Many of the sites have proven difficult to find because of significant changes in land use patterns since the time of $\mathrm{Dr}$. Webb's investigations. Areas that previously were cleared for cultivation or pasture now often are used for timber production. Periodic cutting of the timber has produced dense thickets with little or no surface visibility. Several sites from which Dr. Webb made large surface collections. now are visible only as small artifact scatters exposed in eroded portions of logging rosds.

Despite the changes in land use, most of the investigated sites remain in good condition. Summaries of six sites in DeSoto Parish and one in Natchitoches Parish are presented here.

\section{Keatchie Site (16 DS 1)}

The Keatchie Site (16 DS 1) is a large scatter of pottery and chipped stone located on the south bank of Keatchie bayou. The deposits consist of 20 to $70 \mathrm{~cm}$ of sandy loam overlying a dense, reddish-brown clay. A dark midden deposit containing a high density of sherds, chipping debris, and faunal remains also is present. Dense vegetation precludes delimitation of boundaries for either the midden or site. However, cultural material is scattered over an area of at least $150 \mathrm{~m}$ by $100 \mathrm{~m}$. Immediately east of the site, Keatchie Bayou has exposed a layer of gray clay that might have been useful as a raw material for ceramic manufacture.

Dr. Webb's 1967 notes concerning this site list a variety of recovered projectile points including Gary, Ellis, Kent, lozenge, Carrollton, Ensor, Macon, and Evans. Triangular, ovoid, and irregular bifaces, along with 
large flake scrapers, manos, and pitted manos also were found. Arrow points include Alba, Scallorn, and Bassett. Most of the pottery is bone tempered and brushing is the dominant surface treatment. Smaller numbers of incised and engraved sherds also are present. Dr. Webb typed two sherds as Marksville or Yokena Incised. He interpreted the pottery component as a somewhat aberrant manifestation of the Bossier Focus.

The site remains in good condition. There is subtle evidence of past excavation in the form of a shallow trench now visible only as a shallow depression in the midden area. Because of the dense vegetation artifacts are not easily seen and the site seems well protected. The area is used for timber production and has been leased to a hunting club.

The Keatchie site has high research potential, particularly since it is apparent that a significant amount of faunal material is preserved in the midden. The possibility of structural remains and other features also is high.

\section{Smithport Landing Site (16 DS 4)}

The Smithport Lianding Site is located south of Smithport Lake where Buffalo Bayou empties into the swamp known as Bayou Pierre Lake. The site is situated on a series of low knolls formed from erosion of the Prairie Terrace. The site is well known (Webb 1963), but its exact location has been in doubt. However, careful study of Webb's descriptions and map leaves little doubt that the site has been re-located.

The area now is in mixed forest and surface visibility is low. A small number of plain sherds were found during the 1990 re-visit. Although the area now is used for timber production and surface visibility is poor, during the 1930 's much of the area was cleared and cultivated. Remains of several tenant houses are visible. It is interesting to note that surface collections from the plowed midden and excavation of the burials at the Smithport Landing site provided the first and still most comprehensive data concerning early Caddo ceramic assemblages in the region. However, if initially encountered today, the site would likely be recorded as several small ceramic scatters. These probably would be interpreted as limitedactivity loci or ephemerally-occupied camps and it is doubtful that much interest would be shown in more intensive investigations.

The Smithport Landing Site appears to have sustained very little damage since the excavations of Dr. Webb and Monroe Dodd in the 1930's. Several depressions found in the southern portion of the site may represent old excavations, but negative impacts appear to be minimal. The site still has high potential to yield significant information.

\section{Williams Point (16 DS 5)}

This is a large site with a high density and diverse range of artifacts. The area currently contains numerous houses and several landowners reportedly have large artifact collections. The site is situated 
on a spur of land that projects eastward into Smithport Lake. The spur is the end of a ridge that is a remnant of the Prairie Terrace.

Although much of the area is disturbed by modern structures and roads, the artifact scatter is visible across the entire ridge. A concentration of sherds and chipping debris is visible in the garden of one of the landowners who also has a large collection (several specimens have been donated to the Williamson Museum collections).

Dr. Webb noted that in 1935 road grading uncovered a burial that contained a Pease Brushed-Incised vessel and an elbow pipe. His notes and collections indicate that the site has multiple components. PalooIndian artifacts include San Patrice points, beveled scrapers, and Albany spokeshaves. The Archaic Period is represented by Gary, Ellis, Macon, Elam, Ensor, Wells, lozenge, Kent, Pontchartrain, Frio, Evans, and Morhiss points. Dr. Webb believed that the pottery (which includes the types Hardy Incised, Dunkin Incised, Sanson Incised, Karnack Brushed-Incised, Pease Brushed-Incised, Belcher Ridged, Pennington-Rhinehart zoned and free punctated, Wilkinson Punctated, and untyped engraved sherds) represents the Alto-early Bossier transition. Alba, Friley, Scallorn, Hayes, and Catahoula arrow points also were recovered.

The Williams Point Site appears to have been occupled over a long span of time and cultural deposits are not deep or stratified. Although many artifacts remain on the site, the overall horizontal spatial structure has been altered significantly by modern land use.

\section{Hewitt Mound No. 1 (16 DS 7)}

The number 16 DS 7 initially was assigned to two sites containing isolated conical mounds. However, because the mounds are located at a distance of more than $1 \mathrm{~km}$ from one another a new number (16 DS 270) has been assigned to the northern mound, the second described by Webb in his 1982 paper on the Bellevue Focus (Webb 1982). Thus, 16 DS 7 now refers only to the southern mound.

The site is situated at the edge of the eroded Prairie Terrace on the north side of Smithport Lake. The mound projects 2-3 $\mathrm{m}$ above the surrounding terrace and is a little over $20 \mathrm{~m}$ in diameter. It has been partially truncated by pothunting. Four large pits are visible in the top, two are about $1 \mathrm{~m}$ deep, two are more shallow. The sides of the pits are slumped and the pits are filled with recent slopewash and leaves. None of the pits appear to represent recent excavations. A trench about $1 \mathrm{~m}$ wide and $1 \mathrm{~m}$ deep is visible in the south side of the mound. It, too, looks like an old excavation. Judging by an eroded area on the south side of the mound, the upper $50 \mathrm{~cm}$ of moundfill appears to consist of loosely compacted brown loamy sand. This gand is underlain by reddish loamy sand that has a mottled appearance.

No associated village or midden debris is visible, but leaf litter and humus completely cover the surrounding surface. A few flakes and small plain sherds are present in a road cut approximately $60 \mathrm{~m}$ west of the mound. 
Dr. Webb (personal communication) believes that the excavations were made primarily by L.S. Frierson, Jr. (now deceased), and that he recovered a large quartz crystal biface from this mound (see Webb 1982:267-268). The possibility that the site is related to the little known Bellevue Focus makes the site valuable for future research.

\section{Hewitt Mound No, 2 (16 DS 270)}

The northern Hewitt Mound was assigned the new number 16 DS 270. Because this is the second mound discussed by Webb (1982) it is referred to as Hewitt Mound No. 2. The site is located directly across the lake from the Williams Point site (16 DS 5). The mound is situated on a long narrow ridge that represents an eroded portion of the Prairie Terrace. The mound is approximately $3 \mathrm{~m}$ higher than the terrace on the west (lake) side, and $1.5 \mathrm{~m}$ higher than the terrace on the east (ridge) side. Five potholes plus a trench, all 50-70 cm deep, are visible in the top of the mound. The pits appear to be more recent than those at $16 \mathrm{DS} 7$; one is bell shaped and looks as though someone has carefully excavated around a vessel and removed it. Very dark deposits, perhaps representing a midden, are located about $25 \mathrm{~m}$ east of the mound. However, the surface is almost totally obscured by leaf litter. A single small rim sherd with no visible decoration was collected from this area.

Like Hewitt Mound No. 1, this site is in good condition despite the mound excavations and there is high potential for addressing significant research questions here.

\section{Thigpen Mound (16 D8 12)}

The Thigpen Mound is located on top of a steep bluff overlooking Bayou Pierre in northeastern Desoto Parish. The bluff is a remnant of the Pleistocene Prairie Terrace. The site consists of a single conical mound, approximately 2.5 to $3 \mathrm{~m}$ high and 15 to $20 \mathrm{~m}$ in diameter. A surface depression, filled with water at the time of the site visit, is present immediately north of the mound. The depression likely represents a borrow area used for mound construction. The mound and surrounding areas currently are covered in weeds and medium to large trees. No artifacts are visible on the site surface. A very large and deep pit has been excavated into the top of the mound, but the pit appears to have been made many years ago. The current landowner stated that the mound has been in its present state since he acquired the property during the early 1960 's.

Dr. Webb acquired a fairly large collection of sherds from the site and classified them as Dunkin and Hardy Incised, Weches Impressed, Wilkinson Punctated, Hickory Engraved, vertical and diagonal incised with notched rims, Bossier Brushed, Pease Brushed-Incised, Belcher Ridged, and plain. Stone artifacts consisted of Gary points, one oval knife, and a Gahagan biface fragment. Dr. Webb (personal communication) found the latter artifact on the site surface, 10 to $15 \mathrm{~m}$ from the mound. 
No sherds were found in the surrounding fields at the time of the 1990 site visit, but surface visibility was low and no shovel tests were employed. The site might contain significant research data despite the damage to the mound, but more intensive testing is necessary.

Richards Site (16 NA 399)

Also of interest is the Richards Site in northern Natchitoches Parish. This site was visited by Dr. Webb (personal communication) and numbered $\mathrm{N}-4$, but a state number never was assigned. The site is situated on a bluff overlooking Jim's River only a few kilometers south of the Hanna Site (Thomas et al. 1980). Like Hanna, the Richards Site appears to be a large, intensively-occupied early Caddo site.

The landowner has a house and several gardens on the site and has acquired a substantial collection of artifacts. However, numerous ceramic and chipped stone artifacts remain on the surface. It appears that several isolated midden deposits may be present. Although negative impacts have occurred from modern activities, the site is in good condition and has high potential for yielding significant research data.

\section{Upcoming Projects by the Regional Archaeology Program}

The ongoing project of re-visiting each of the sites recorded by Dr. Webb will continue during the next year. In addition a project has been started to record sites along the shoreline and major drainages on the Louisiana side of Toledo Bend Reservoir. Relatively few archaeological sites have been recorded along the shoreline, but reports of sites being exposed with water level fluctuations are numerous. The area apparently is being hit hard by collectors and the pace of residential and recreational development near the reservoir is accelerating. Information acquired from the survey will be presented in future issues of Caddo Archaeology.

\section{References Cited}

Thomas, Prentice Marquet, Jr., L. Janice Campbell, and Steven $R$. Ahler

1980 The Hanna Site, An Alto Village in Red River Parish. Louisiana Archaeology No. 5.

Webb, Clarence $\mathrm{H}$.

1982 The Bellevue Focus: A Marksville-Troyville

Manifestation In Morthwestern Louisiana. Louisiana Archaeology 9:251-274. 